\title{
Compulsive buying and credit card misuse among credit card holders: The roles of self-esteem, materialism, impulsive buying and budget constraint
}

\author{
Nor Asiah Omar, Ruzita Abdul Rahim, Che Aniza Che Wel, Syed Shah Alam \\ School of Management, Universiti Kebangsaan Malaysia, National University of Malaysia \\ (Malaysia)
}

norasiah@ukm.my,ruzitaar@ukm.my,aniza@ukm.my,shahalam@ukm.my

\section{Abstract}

Purpose: This study aims to examine the factors that influence credit card misuse among working adults in Klang Valley, Malaysia. The relationship among self-esteem, materialism, impulsive buying, budget constraint, compulsive buying and credit card misuse are explored in this study.

Design/methodology/approach: A total of 186 questionnaires was collected via convenience sampling from credit card users of working adults in Malaysia. A structural equation model that assesses the relationship between the proposed variables is tested using AMOS 20.

Findings: The findings reveal that budget constraints, impulsive buying and materialism have a statistically significant influence on compulsive buying. In terms of credit card misuse, it is influenced negatively by self-esteem while positively by compulsive buying.

Originality/value: Despite vast research on compulsive buying and credit card misuse, very few studies have examined it in the non-Western context. 
Keywords: Credit card, compulsive buying, self-esteem, materialism, impulsive buying, budget constraints, Malaysia

Jel Codes: M31

\section{Introduction}

Credit card is a mode of payment that is widely used by consumers to purchase goods and services on credit. The growth in credit card usage is parallel with the growth in other types of consumer credits such as bank overdrafts, personal loans, hire purchase and others. Although credit card stimulates consumer spending (Warwick \& Mansfield, 2000) and offers flexibility to consumers, it also has its setbacks. The current developments of financial services globally have increased the availability and usage of credit, and directly increase the indebtedness of consumers (Griffiths, 2000). According to Soman (2001), those who use credit cards usually will make extra purchases and also tend to spend over their means. Consequently, they carry large balances in their credit cards which tend to accumulate because they usually pay only the minimum amount required by the banks.

This trend seems to be felt in Malaysia where the spread of credit card usage has been overwhelming among the consumers. As reported in Passport (2011), personal credit cards in Malaysia are dominating 92 percent of transaction volume and 89 percent of transaction value in 2010. The transaction value of credit cards increases from RM41,228.1 million in 2005 to RM74,783.7 million in 2010 and the number of credit cards issued increase from 7.86 million in 2005 to 10.69 million in 2010. What is then the negative side of this development? Ahmed, Ishak Ismail, Sadiq Sohail, Ibrahim Tabsh and Hasbalaila Alias (2010) noted that many Malaysian consumers display compulsive buying behaviour, and with the easy accessibility to credit, this behaviour has led to exorbitant debt. The problem worsens because cardholders in Malaysia also use credit cards to withdraw cash advance. In this sense, credit cards are taken as the most consumer-friendly loan because it is easier to apply for credit cards than personal loans.

When credit cards were first introduced in Malaysia in the mid-1970s, only the well-off individuals (professionals and successful businesspersons)are eligible to own a credit card, which then represented the symbol of prestige (Loke, 2007). The requirement to own a credit card has been continuously relaxed as time passes. According to Ahmed et al. (2010), the rapid growing of Malaysian credit cardholders has created a thoughtless and unselective spending by users that cause many side effects. Furthermore, many Malaysian consumers are prone to exhibit compulsive buying behaviour. In an environment such as this, easy accessibility to credit cards has led to harmful circumstances such as excessive debts among 
Malaysians. The government of Malaysia is concerned about the increase in credit card usage and is keen to reduce personal debts. In 2010, the government introduces RM50 service tax for credit cards to promote a prudential approach to control credit cards. This action has effectively motivated many cardholders to cancel some of their credit cards especially in the wake of the economic downturn. Earlier in 2009, the Association of Banks in Malaysia restructured the credit card interest rates in order to encourage consumers to pay their credit cards, promptly.

Recently, the Central Bank of Malaysia (more commonly known as Bank Negara Malaysia) reported that as at end of 2010, the numbers of credit cardholders were 3.2 million with an outstanding credit card debt amounted to RM30.8 billion. This figure was 5 percent of the total household debt while non-performing loans (NPL) remained low at 1.7 percent of total credit card loans and 2 percent of the total banking system NPLs. With the current economic situation, the BNM has announced a new and more stringent set of guidelines on credit card eligibility criteria in March 2011 to promote prudent financial management among credit card users and to encourage responsible business practices among the credit card issuers.

Like the policy makers, the consumers are also concerned about the escalation of the credit card debt (Geisst, 2009; Gross \& Souleles, 2002). Bernthal, Crockett and Rose (2005) noted that consumers use credit cards to support their lifestyles. The increasing number of consumers especially among the young adults who incur debts in their credit cards is worrisome, particularly because they appear to be ignorant about the future consequences of their indebtedness (Roberts \& Jones, 2001). Although previous research has investigated the factors that influence the compulsive buying (Dittmar, 2005; Park \& Burns, 2005; Gao, Wheeler \& Shiv, 2009) and credit card usage (Pirog \& Roberts, 2007; Fitzmaurice, 2008), few have systematically articulated how these factors influence credit card misuse with theoretical support. Additionally, the findings of these studies are mainly derived from Western context. Therefore, it is unclear whether similar findings will be found in a non-Western context. In their study, Sidoti and Devasagayam (2010) focused on the effect of materialism and risk attitude on credit card misuse in Western countries. Little research has been done in the Malaysian context. Palan, Morrow, Trapp and Blackburn (2011) examine the mediating effects of credit card usage on the relationship between self-esteem and compulsive buying behaviour. According to Hayhoe, Leach, Turner, Bruin and Lawrence (2000), income can also influence credit card usage among college students. However, Lyons (2004) suggested that only students with need-based financial aids are exposed to credit card debt.

Therefore, in an attempt to bridge these gaps, this study examines how self-esteem, materialism, budget constraint and impulsive buying influence compulsive buying and credit 
card misuse among working adults in Selangor, Malaysia. Moreover, this study also investigates the relationship between compulsive buying and credit card misuse. The variables of this study have been identified based on an extensive review of literatures. The findings of this study implicate need for training in financial planning to promote responsible spending among Malaysian.

The remainder of the article is organized as follows. Section 2 presents the literature review, followed by the hypotheses. Section 3 describes the research methodology, sampling technique, as well as validity and reliability tests of the instruments used in this study. Sections 4 and 5 analyse and discuss the results. The last section summarizes findings of this study and provides implications arising from the findings.

\section{Literature Review}

\subsection{Self-Esteem}

Self-esteem is defined as an individual's feelings about the value or worth of himself or herself, and it is the degree of positivity of the self-concept (Rosenberg, 1979). Self-esteem signals individual's interpretations of the way others think about him or her (Cooley, 1902; Rosenberg, 1979). Pettit and Sivanathan (2011) find that individuals with low self-esteem tend to purchase expensive luxury goods on credit to repair their self-worth. This finding supports Bell's (1998) argument that in a modern society, material wealth is used to demonstrate their social power. Similarly, Eastman, Fredenberger, Campbell and Calvert (1997) posited that status is shown by ownership of status products rather than occupational or personal reputation. These arguments are also consistent with Prince (1993) who suggested that young adults related money closely with power and esteem. In an earlier study, Braun and Wicklund (1989) noted that people demonstrate their identity to others by possessions of luxury items. However, this behaviour is conditional because it prevails when their identity is threatened. In a recent study, Gao et al. (2009) found that other psychological states such as low self-view confidence also can induce compensatory status consumption.

If low self-esteem lead to compulsive buying (Faber \& O'Guinn, 1992) or high spur to purchase (d'Astous, 1990), how does this personality lead to credit card misuse? The answer lies in Wang, Lv and Jiang's (2011) explanation. When consumers' income is insufficient to meet their demand in pursuit of prestige, they will buy the luxury products using credit cards. The same problem less likely to occur among individuals of high self-esteem because they are more confident and less affected emotionally. In contrast, low self-esteem people continuously experience higher anxiety, distress and negative emotions (Yelsma, P. \& Yelsma, J., 1998). 
Credit card misuse is more likely to implicate this group of individual because most of the time compulsive buying happens in consumers who are very concerned about their appearance to others and attempt to be pleasing others (Krueger, 1988).Empirically, there is no significant relationship between self-esteem and credit card debt (Pinto, Mansfield \& Parente, 2004). However, the picture becomes clearer when the definition of debt is widened to include all kinds of borrowings. Norvilitis, Merwin, Osberg, Roehling, Young and Kamas (2006) found a negative relationship between self-esteem and acquisition of debt, although it cannot be verified whether low self-esteem triggers individual's tendency to incur more debts whether debt reduces self-esteem, or whether another third factor exists. Inspired by these ideas and findings, we proposed the following hypotheses:

- H1a. Self-esteem will have a negative effect on compulsive buying behaviour.

- H2a. Self-esteem will have a negative effect on credit card misuse.

\subsection{Materialism}

Materialism is the individual's devotion to material desires, drive on getting more material things, and attachment to worldly possessions to achieve desired states. Materialists treat acquisition of goods as their personal goals that affect their lifestyles (Richins \& Dawson, 1992). Schiffman and Kanuk (2007) noted that materialism stresses possessions as the central of an individual's identity attribution to success. At the most extreme degree of materialism, individuals treat possession as the greatest satisfaction and pleasures in life (Belk, 1984). Accessibility to credit card can be detrimental to materialists because they tend to experience more dissatisfaction for setting unrealistic goals in their lives Sirgy (1998). Credit card provides a means for them to reach these goals, but this means is artificial because it is not supported with actual resources. Consistent with Sirgy (1998), Dittmar, Long and Bond (2007) found that individuals who are materialistic are less satisfied and more likely to be compulsive buyers. Therefore, the desire to attain social status through material possessions can easily trigger temptation, causing splurge spending which probably lead to credit card misuse (Fitzmaurice, 2008; Pirog \& Roberts, 2007; Richins, 2011).

Rischins and Rudimin (1994) suggested that materialistic tendencies are related to the individual's identity, social behaviour, motivation for work and use of money. In turn, individuals' attitudes toward money and credit are related to their spending behaviour, economic well-being, and tolerant to debt levels (Lea, 1995). According to Kasser and Sheldon (2000), when individuals' needs for security and safety are not fully satisfied, they will turn their focus on materialistic needs including purchasing expensive things to achieve the desired 
states. The tendency could impose a serious problem to the economic well-being of the society because the increasing drive towards materialism, which contributes to compulsive buying behaviour, has been found to also occur among the younger consumers (Dittmar, 2005). This notion is supported by a finding by Heaney, Goldsmith and Jusoh (2005) which shows that there is a significant relationship between status consumption and materialism among college students. Consistent with the evidence presented by previous researchers, we therefore postulate that:

- H1b. Materialism will have a positive effect on compulsive buying behaviour.

- H2b. Materialism will have a positive effect on credit card misuse.

\subsection{Budget Constraint}

Consumer demand theory suggests that consumers maximise utility, which is subject to budget constraints, where price and income influence the budget constraints (Pindyck \& Rubinfeld, 2008). According to Hayhoe et al. (2000), the income of college students, whether the sources are part-time jobs, sponsorships, or parents, also influence their credit card usage. They found that students with higher income tend to purchase entertainment, clothes and fuel with credit cards. Students with need-based financial aids are exposed to credit card debt (Lyons, 2004) but parental income is not associated with college students with credit card debt (Wang \& Xiao, 2009). These findings suggest that students claim personal ownership on the financial aids that they are free to spend the funds according to their own needs, interests, or desires. In contrast, they have fewer tendencies treat parental income in a similar manner because they have to answer to their parents out of respects, gratitude or responsibility.

A recent finding by Fogel and Schneider (2011) suggests that even the high disposable income consumers are exhibiting compulsive buying because they use it as a coping or therapeutic approach. In a case such as this, compulsive buying may not lead to credit card misuse if the disposable income is high enough to support the compulsive buying behaviour. Based on this, we state the following hypothesis:

- H1c. Budget constraint is related to compulsive buying behaviour. 


\subsection{Impulsive Buying}

Impulse buying happens when an individual experiences a persistent, and sudden and powerful urge to instantly purchase something (Rook, 1987) and it could result from temporary failure of self-control (Baumeister, 2002). It happens when there is no pre-shopping intention to purchase the specific product or to fulfil specific buying task (Beatty \& Ferrell, 1998). The possibility of unplanned and unwanted outcomes is high when individuals act on impulse (Rook \& Fisher, 1995). However, impulse consumers tend to give in to their buying temptation although they are aware of the negative consequences (Rook, 1987). When the impulse is out of control, the impulsive consumers have a great tendency to misuse their credit cards because credit cards provide a readily accessible means to fulfil their self-generated desires for things (Pirog \& Roberts, 2007; Rook \& Fisher, 1995; Roberts \& Jones, 2001).

Several studies (Fogel \& Schneider, 2011; Park \& Burns, 2005 have discovered significant positive relationships between fashion orientations in both impulsive and compulsive spenders. Impulsive spending happens spontaneously in response to in-store stimulus, whereas compulsive spending is an addictive form of compensatory consumption (Bayley \& Nancarrow, 1998; Shoham \& Brencic, 2003; Woodruffe, 1997). Based on the reported research, we proposed the following hypotheses:

- H1d. Impulse buying tendencies will have a positive effect on compulsive buying behaviour.

- H2c. Impulse buying tendencies will have a positive effect on credit card misuse.

\subsection{Compulsive Buying}

Compulsive buying can be defined as a chronic, repetitive purchasing that is induced by negative events or feelings (Faber \& O'Guinn, 1989). This behaviour is a critical tendency of an individual to spend beyond his/her means and needs (Mittal, Huppertz \& Khare, 2008) and it is becoming a serious problem among consumers (Mittal et al., 2008). Chaplin and John (2007) asserted that the modern culture that embraces materialism has intensified compulsive buying behaviour and Roberts and Jones (2001) claimed that compulsive buying has been identifies as one of the greatest cause associated with credit debts. People purchase expensive material goods to demonstrate status, social power and economic power to fulfil pleasure-seeking needs (Bell, 1998; Belk, 1984) and to camouflage the low self-esteem (Faber \& O'Guinn, 1992; Hanley \& Wilhelm 1992). The desire to attain social status through material possessions has encouraged the splurge spending and credit card misuse (Fitzmaurice, 2008; Pirog \& Roberts, 
2007; Dittmar et al., 2007). Hence, based on previous literature, we predict the following relationships:

- H3. Compulsive buying will have a positive effect on credit card misuse.

\subsection{Credit Card Misuse}

Credit card misuse refers to excessive and irresponsible spending using credit card that causes credit card debt (Norvilitis et al., 2006; Palan et al., 2011; Sidoti \& Devasagayam, 2010). Consumers are more likely to misuse their credit cards if they see money as a source of prestige (Tokunaga, 1993) and they will buy the luxury products using credit cards in pursuit of their desires (Wang et al., 2011). Similarly, individuals with low self-esteem purchase expensive luxury goods on credit to repair their self-worth (Pettit \& Sivanathan, 2011). Credit card misuse is also more likely among individuals who are impulsive buyers (Pirog \& Roberts, 2007), students with need-based financial aids (Lyons, 2004), and compulsive buyers (d'Astous, 1990; Faber \& O'Guinn, 1992; Ritzer 1995).

\subsection{Research Objectives and Research Model}

The main objective of the study is to investigate if self-esteem, materialism, budget constraint and impulsive buying are key factors that contribute to compulsive buying and credit card misuse among working adults in Malaysia. This study also aims to examine the relationship between compulsive buying and credit card misuse. The research model is based on past studies (Faber \& O'Guinn, 1992; Calvert, 1993; Richins \& Dawson, 1992; Roberts \& Jones, 2001; Rook \& Fisher, 1995; Rosenberg, 1965; Urbany, Dickson \& Kalapurakal, 1996; Yamuchi \& Templer, 1982). This model depicted in figure 1 , relates the independent and dependent variables without any intervening variables. The model consists of four variables that we posit to have an effect on compulsive buying behaviour and credit card misuse. The hypothesized relationships between these variables are illustrated in Figure 1. 


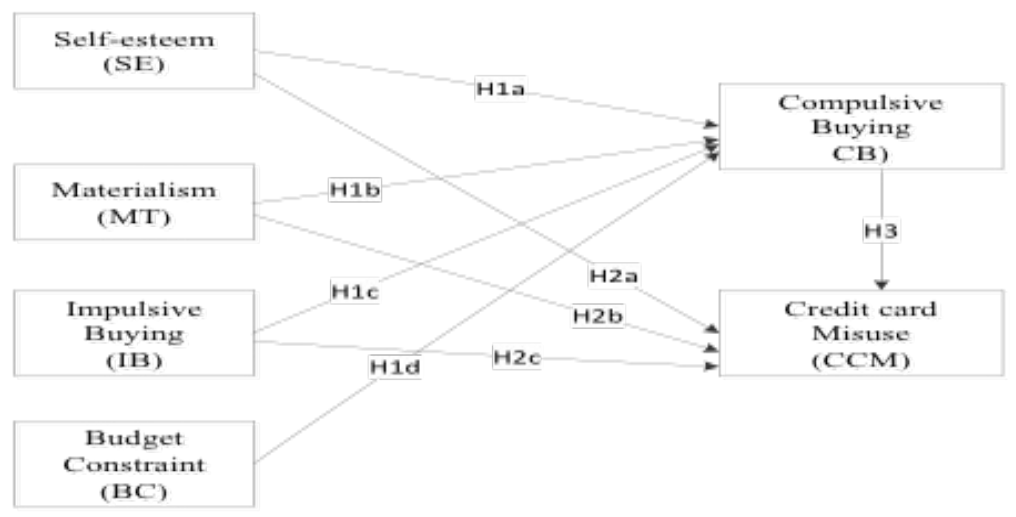

Figure 1. Research Model

\section{Research Methodology}

\subsection{Sampling Design and Procedures}

A self-administered questionnaire survey was distributed using convenient sampling to collect the empirical data. The target population comprises of credit card users and those who live or work within Klang Valley, Malaysia. Klang Valley is where the capital city of Malaysia, Kuala Lumpur, is situated. The Federal Territory of Kuala Lumpur has the highest population density in the Malaysia i.e., about 6,500 people per square kilometre. This metropolitan city is situated in the state of Selangor, which is one of the 14 states in Malaysia that is experiencing the fastest rise in population density as it benefits from the rapid development of Kuala Lumpur and the spill over of residents across the state boundary which surrounds the Federal Territory (Passport, 2011).

A total of 230 responses were collected. After data cleaning and editing, the final count of questionnaires with no missing values for all variables under analysis was 186 , representing a response rate of 81 percent. Table 1 reported the demographic profiles of the respondents. There were about the same number of male and female respondents. About 47.3 percent of the respondents were from the 20-30 age group followed by 35.3percent from the 31-40 age groups, giving a total of 82 percent of total respondents. Majority of the respondents (60\%) were ethnic Malay, 30 percent were ethnic Chinese, while 10 percent were ethnic Indians and the "other" ethnic groups. Most of the respondents held executive posts or higher. The occupations explained their income levels. Nearly half of the respondents earned RM2,001RM4,000 per month, about a quarter earned RM4,001-RM6,000 while 23.3 percent earned more than RM6,000. There were 70.7 percent of the respondents who attained a Bachelor degree, 20 percent were with a Master degree and only 1 person had a PhD qualification. 


\begin{tabular}{|c|c|c|c|}
\hline \multirow{2}{*}{\multicolumn{2}{|c|}{ Demographic Variable }} & \multicolumn{2}{|c|}{ Respondents $(\mathrm{N}=186)$} \\
\hline & & \multirow{2}{*}{$\begin{array}{ll}\text { Number } & \\
91\end{array}$} & \multirow{3}{*}{$\begin{array}{r}\text { Percentage } \\
48.7 \\
51.3\end{array}$} \\
\hline Sex & Male & & \\
\hline \multirow{5}{*}{ Ethnic } & Female & & \\
\hline & Malay & 112 & 60.0 \\
\hline & Chinese & 56 & 30.0 \\
\hline & Indian & 16 & 9.3 \\
\hline & Others & 1 & 0.7 \\
\hline \multirow{5}{*}{ Age } & Less than 20 years old & 3 & 1.3 \\
\hline & $20-30$ & 88 & 47.3 \\
\hline & $31-40$ & 66 & 35.3 \\
\hline & $40-50$ & 22 & 12.0 \\
\hline & Above 50 years old & 7 & 4.0 \\
\hline \multirow{5}{*}{ Income } & Below RM2,000 & 12 & 6.7 \\
\hline & RM2,001 - RM4,000 & 83 & 44.7 \\
\hline & RM4,001- RM6,000 & 48 & 25.3 \\
\hline & RM6,001 - RM8,000 & 19 & 10.0 \\
\hline & Above RM 8,001 & 24 & 13.3 \\
\hline \multirow{5}{*}{ Occupation Level } & Students/Non-Executive & 2 & 1.3 \\
\hline & Non-Executive & 19 & 10.0 \\
\hline & Executive & 106 & 57.3 \\
\hline & Manager & 48 & 25.3 \\
\hline & Top-Management & 11 & 6.0 \\
\hline \multirow{5}{*}{ Education Level } & SPM & 7 & 4.0 \\
\hline & STPM / Diploma & 8 & 4.7 \\
\hline & Degree & 133 & 70.7 \\
\hline & Master Degree & 37 & 20.0 \\
\hline & PHD & 1 & 0.7 \\
\hline
\end{tabular}

Table 1. Demographic Profile of Respondents

Table 2 reported the patterns of the credit card usage. There were a total of 265 credit cards used, because more than half of the respondents' owned 2 or more credit cards. From the 265 credit cards, 44.2 percent were Master cards, 45.3 percent were Visa cards while the remaining 10.5 percent were AMEX or Diners cards. There were 36.7 percent of the respondents who used their credit cards once a week, followed by 26.7 percent who used fortnightly, and almost 10 percent used them on a daily basis. Only 27.3 percent of the respondents used the cards once a month. The most popular use of credit card was shopping $(52.7 \%)$, followed by groceries, business, purely personal reason, and entertainment. The other purposes of credit card usage were convenience, payment for insurance, medical and online ticket. 


\begin{tabular}{|c|c|c|c|}
\hline \multirow{2}{*}{\multicolumn{2}{|c|}{ Credit Card Usage Variable }} & \multicolumn{2}{|c|}{ Respondents $(\mathrm{N}=186)$} \\
\hline & & Number & Percentage \\
\hline Type of Credit Card & $\begin{array}{l}\text { Master } \\
\text { Visa } \\
\text { AMEX } \\
\text { Diners } \\
\text { Others }\end{array}$ & $\begin{array}{r}117 \\
120 \\
26 \\
2 \\
0\end{array}$ & $\begin{array}{r}44.2 \\
45.2 \\
9.8 \\
0.8 \\
0\end{array}$ \\
\hline $\begin{array}{l}\text { Number of Credit } \\
\text { Card }\end{array}$ & $\begin{array}{l}\text { Only } 1 \\
2-4 \\
5-7 \\
8-10\end{array}$ & $\begin{array}{r}92 \\
86 \\
6 \\
2\end{array}$ & $\begin{array}{r}49.3 \\
46.0 \\
3.3 \\
1.3\end{array}$ \\
\hline Usage frequencies & $\begin{array}{l}\text { Once a month } \\
\text { Once fortnightly } \\
\text { Once a week } \\
\text { Everyday }\end{array}$ & $\begin{array}{l}51 \\
50 \\
68 \\
17\end{array}$ & $\begin{array}{r}27.3 \\
26.7 \\
36.7 \\
9.3\end{array}$ \\
\hline Purpose of Usage & $\begin{array}{l}\text { Business } \\
\text { Shopping } \\
\text { Groceries } \\
\text { Entertainment } \\
\text { Purely personal reason } \\
\text { Education } \\
\text { Others } \\
\text { - } \text { Convenience } \\
\text { - } \text { Insurance } \\
\text { - } \text { Medical } \\
\text { - } \text { Online ticket }\end{array}$ & $\begin{array}{r}42 \\
98 \\
72 \\
24 \\
29 \\
24 \\
26 \\
2 \\
3 \\
1 \\
1 \\
17\end{array}$ & $\begin{array}{r}22.7 \\
52.7 \\
38.7 \\
13.3 \\
16.0 \\
12.7 \\
14.0 \\
1.3 \\
2.0 \\
0.7 \\
0.7 \\
9.3\end{array}$ \\
\hline
\end{tabular}

Table 2. Patterns of Credit Card Usage

\subsection{Operational Definitions of Variables}

The Appendix exhibited measures for the six variables in this study which were either adopted or adapted from the related studies. A survey instrument was composed based on the measurement items plus items designed to collect respondent demographics. All questions were measured on a 5-point Likert scale ranging from 1 (strongly disagree) to 5(strongly agree), where respondents indicated their degree of agreement or disagreement with a series of statements. Table 3 reported a reliability analysis of Cronbach alphas of $0.89,0.76,0.85$, $0.88,0.71$, and 0.81 for self-esteem, materialism, impulsive buying, budget constraint, compulsive buying, and credit card misuse, respectively. The results indicated a high degree of internal consistency which concurs with Nunnally's (1978) 0.7 cut-off point. 


\section{Data analysis}

\subsection{Confirmatory Factor Analysis and Structural Model}

A two-step approach was employed to analyse the data, in which an examination of the measurement model was followed by an examination of the structural model to test the hypothesized relationships (Anderson \& Gerbing, 1988). The structural equation modelling (SEM) procedure enabled us to evaluate how well a proposed conceptual model that contained observed variables and unobservable constructs fit the collected data (Bollen, 1989). A confirmatory factor analysis (CFA) was conducted to test the robustness and reliability of the scales (via AMOS and the maximum likelihood estimation technique) to confirm the factor loading of the six constructs and to assess the model fit. The SEM was conducted to assess the overall fit of the proposed model and to test the hypotheses.

The model adequacy was assessed by the fit indices suggested by Hair, Black, Babin, Anderson \& Tatham (2006). The analysis showed the model had an acceptable overall fit ( $2=339.53$, $\mathrm{df}-=138, \mathrm{X} 2 / \mathrm{df}=2.460, p=.000, \mathrm{GFI}=.90, \mathrm{CFI}=.91, \mathrm{RMSEA}=.008)$. Both the GFI and CFI values were larger than the suggested cut-off point of 0.90 (Hu \& Bentker, 1999) while the ratio of chi-square to degrees of freedom (x2/df) of 2.46 indicated a good model fit (Chin \& Todd, 1995). A root mean square of error of approximation (RMSEA) of 0.008 also indicated an acceptable fit (Hair et al., 2006). Overall, the measurement model fit well to suggest adequate validity and to warrant a closer look.

We assessed the convergent and discriminant validity with several tests suggested by Anderson and Gerbing (1988). Tables 3 and 4 listed the Cronbach's alpha, composite reliabilities and variance extracted estimates (AVE). Cronbach's alpha of all dimensions ranged from 0.71 to 0.89 , clearly indicating that the scales used in this study were highly reliable (Nunnally, 1978). The AVE values consistently exceeded the recommended lower standard of 0.50 (Fornell \& Larcker, 1981). All tests supported convergent validity of the scales. We also assessed discriminant validity with tests recommended by Anderson and Gerbing (1988). The correlation index among factors was low to moderate and did not exceed the 0.85 cut-off point (Kline, 2005). Given the satisfactory fit of the model, the estimated structural coefficients were then examined to test the 7 hypothesed relationships using AMOS (see Figure 2). 


\begin{tabular}{|c|c|c|c|c|c|c|}
\hline Construct & Item & $\begin{array}{l}\text { Internal } \\
\text { reliability } \\
\text { cronbach } \\
\text { alpha }\end{array}$ & $\begin{array}{l}\text { Composite } \\
\text { reliability }\end{array}$ & $\begin{array}{l}\text { Average } \\
\text { variance } \\
\text { extracted }\end{array}$ & $\begin{array}{c}\text { Std. } \\
\text { Factor } \\
\text { loading }\end{array}$ & $\begin{array}{l}\text { Std. error } \\
\text { (SE) }\end{array}$ \\
\hline Self-esteem & $\begin{array}{l}\text { SE1 } \\
\text { SE2 } \\
\text { SE3 }\end{array}$ & 0.89 & 0.89 & 0.73 & $\begin{array}{r}0.844 \\
0.878 \\
0.840^{d}\end{array}$ & $\begin{array}{r}0.071 \\
0.066 \\
\end{array}$ \\
\hline Materialism & $\begin{array}{l}\text { MT3 } \\
\text { MT4 } \\
\text { MT6 }\end{array}$ & 0.76 & 0.77 & 0.53 & $\begin{array}{r}0.808 \\
0.806 \\
0.548^{\text {d }}\end{array}$ & $\begin{array}{l}0.211 \\
0.217\end{array}$ \\
\hline $\begin{array}{l}\text { Impulsive } \\
\text { Buying }\end{array}$ & $\begin{array}{l}\text { IB1a } \\
\text { IB2a } \\
\text { IB3a }\end{array}$ & 0.85 & 0.85 & 0.65 & $\begin{array}{r}0.830 \\
0.821 \\
0.768^{\text {d }}\end{array}$ & $\begin{array}{l}0.095 \\
0.101\end{array}$ \\
\hline $\begin{array}{l}\text { Budget } \\
\text { Constraint }\end{array}$ & $\begin{array}{l}\text { BC2 } \\
\text { BC4 } \\
\text { BC5 } \\
\text { BC6 }\end{array}$ & 0.88 & 0.89 & 0.67 & $\begin{array}{r}0.711 \\
0.883 \\
0.873^{d} \\
0.796\end{array}$ & $\begin{array}{r}0.086 \\
0.069 \\
- \\
0.071\end{array}$ \\
\hline $\begin{array}{l}\text { Compulsive } \\
\text { Buying }\end{array}$ & $\begin{array}{l}\text { CB1a } \\
\text { CB2a } \\
\text { CB3a }\end{array}$ & 0.71 & 0.72 & 0.50 & $\begin{array}{c}0.628^{d} \\
0.760 \\
0.651\end{array}$ & $\begin{array}{r}- \\
0.135 \\
0.119\end{array}$ \\
\hline $\begin{array}{l}\text { Credit Card } \\
\text { Misuse }\end{array}$ & $\begin{array}{l}\text { CM2a } \\
\text { CM3a } \\
\text { CM4a }\end{array}$ & 0.81 & 0.81 & 0.59 & $\begin{array}{r}0.696 \\
0.833 \\
0.769^{d}\end{array}$ & $\begin{array}{l}0.098 \\
0.099\end{array}$ \\
\hline
\end{tabular}

Note: ${ }^{\mathrm{d}}$ The first path for each construct was set to 1 , therefore, there is no SEs.

Table 3. Factor Loadings, Reliability and Related Information

\begin{tabular}{|l|r|c|c|c|c|c|c|c|c|c|}
\hline Constructs & Mean $^{\mathrm{a}}$ & \multicolumn{1}{|c|}{ SD } & $\mathbf{a}$ & $\mathbf{C R}$ & $\mathbf{S E}$ & MAT & IB & BC & CB & CCM \\
\hline Self-esteem & 4.31 & 0.93 & 0.89 & 0.89 & $\mathbf{0 . 7 3}$ & & & & & \\
\hline Materialism & 4.37 & 1.05 & 0.76 & 0.77 & 0.11 & $\mathbf{0 . 5 3}$ & & & & \\
\hline $\begin{array}{l}\text { Impulsive } \\
\text { Buying }\end{array}$ & 4.29 & 1.01 & 0.85 & 0.85 & -0.14 & $0.46^{* *}$ & $\mathbf{0 . 6 5}$ & & & \\
\hline $\begin{array}{l}\text { Budget } \\
\text { Constraint }\end{array}$ & 4.42 & 1.18 & 0.88 & 0.89 & $-0.19^{* *}$ & $0.42^{* *}$ & $0.56^{* *}$ & $\mathbf{0 . 6 7}$ & & \\
\hline $\begin{array}{l}\text { Compulsive } \\
\text { Buying }\end{array}$ & 4.37 & 1.03 & 0.71 & 0.72 & $-0.20^{* *}$ & $0.54^{* *}$ & $0.67^{* *}$ & $0.70^{* *}$ & $\mathbf{0 . 5 0}$ & \\
\hline $\begin{array}{l}\text { Credit Card } \\
\text { Misuse }\end{array}$ & 4.47 & 1.01 & 0.81 & 0.81 & $0.23^{*}$ & $0.45^{* *}$ & 0.44 & $0.48^{* *}$ & $0.53^{* *}$ & $\mathbf{0 . 5 9}$ \\
\hline
\end{tabular}

Notes: Diagonals represent the average variance extracted while the other entries represent the squared correlations. ${ }^{* *}$ Correlation is significant at the 0.01 level ( 2 -tailed).

a These mean figures are based on each summated scale score divided by the number of items in each scale, for ease of interpretation; $a=$ Cronbach's alpha; SD = Standard deviation.

Table 4. Discriminant Validity of Constructs

\subsection{Hypotheses Testing}

Hypotheses 1 to 3 addressed the influence of self-esteem, materialism, impulsive buying and budget constraint on compulsive buying and credit card misuse. The SEM performed via AMOS 20 produced $t$ values for all standardized factor loadings to test the hypotheses. Hypotheses $1 a$ 
through 1d predicted that self-esteem, materialism, impulsive buying and budget constraint effected compulsive buying, respectively. The results, reported in Table 5, showed that materialism ( $Y=0.25 ; t=2.85 ; p<0.05)$, impulsive buying $(Y=0.43 ; t=4.57 ; p<0.05)$ and budget constraint $(Y=0.45 ; t=5.07 ; p<0.001$ ) had significant effects on compulsive buying behaviour. Therefore, $\mathrm{H} 1 \mathrm{~b}, \mathrm{H} 1 \mathrm{c}$ and $\mathrm{H} 1 \mathrm{~d}$ cannot be rejected. The most important variable to influence compulsive buying was budget constraint. Meanwhile, self-esteem showed a negative, but insignificant effect on compulsive buying behaviour $(Y=-0.11 ; t=-1.732 ; p>$ 0.05).

Although self-esteem did not significantly influence compulsive buying, this variable was statistically significant $(Y=-0.23 ; t=-2.62 ; p<0.05)$ in explaining credit card misuse. The strong tendency to misuse credit cards was high among these individuals because as explained by Pettit and Sivanathan (2011), they tended to purchase expensive luxury goods on credit to increase their sense of self-worth. While hypothesis $2 a$ was supported, the direct paths from materialism and impulsive buying to credit card misuse were not significant $(\gamma=0.25$; $\mathrm{t}=1.78 ; \mathrm{p}>0.05 ; \mathrm{y}=-0.07 ; t=-0.37 ; p>0.05$, respectively), which meant that $\mathrm{H} 2 \mathrm{~b}$ and $\mathrm{H} 2 \mathrm{c}$ were not supported.

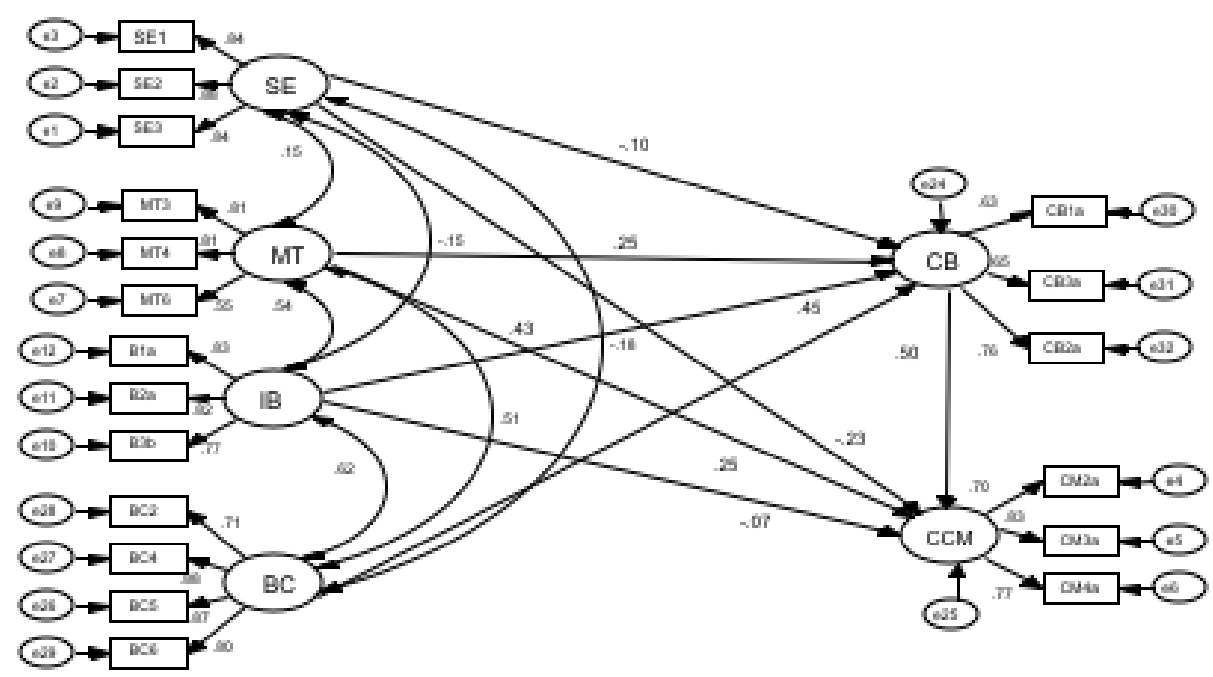

Figure 2. Results of The Structural Model 
Finally, H3, which suggested that compulsive buying behaviour influences credit card misuse, was supported ( $\beta=0.50 ; t=2.144 ; p<0.05)$. Overall, the findings rejected the roles of materialism and impulsive buying in inducing credit card misuse while at the same time emphasized the roles of compulsive buying and self-esteem in influencing credit card misuse among credit card users.

\begin{tabular}{|c|c|c|c|c|}
\hline \multicolumn{2}{|c|}{ Hypothesized Path } & \multirow{2}{*}{$\begin{array}{r}\begin{array}{c}\text { Standardized } \\
\text { Coefficient }\end{array} \\
-0.11\end{array}$} & \multirow{2}{*}{$\begin{array}{c}\begin{array}{c}\text { Critical } \\
\text { Ratio } \\
\text { (t-value) }\end{array} \\
-1.73^{n . s}\end{array}$} & \multirow{2}{*}{$\begin{array}{c}\text { Results } \\
\text { Not } \\
\text { supported }\end{array}$} \\
\hline H1a & Self-esteem - Compulsive buying & & & \\
\hline H1b & Materialism - Compulsive buying & 0.25 & $2.85^{*}$ & Supported \\
\hline H1c & $\begin{array}{l}\text { Impulsive buying - Compulsive } \\
\text { buying }\end{array}$ & 0.43 & $4.57 *$ & Supported \\
\hline H1d & $\begin{array}{l}\text { Budget constraint - Compulsive } \\
\text { buying }\end{array}$ & 0.45 & $5.07 *$ & Supported \\
\hline $\mathrm{H2a}$ & Self-esteem - Credit card misuse & -0.23 & $-2.62 *$ & Supported \\
\hline H2b & Materialism - Credit card misuse & 0.25 & $1.78^{\text {n.s }}$ & $\begin{array}{c}\text { Not } \\
\text { supported }\end{array}$ \\
\hline H2c & $\begin{array}{l}\text { Impulsive buying - Credit card } \\
\text { misuse }\end{array}$ & -0.07 & $-0.37^{n . s}$ & $\begin{array}{c}\text { Not } \\
\text { supported }\end{array}$ \\
\hline H3 & $\begin{array}{l}\text { Compulsive buying- Credit card } \\
\text { misuse }\end{array}$ & 0.50 & $2.14^{*}$ & Supported \\
\hline
\end{tabular}

* Significant at $\mathrm{p}<0.05$ ( $\mathrm{t}> \pm 1.96) ;$ n.s Non-significant

Table 5. Results of the Hypotheses Testing

\section{Discussion}

The findings of this study could make significant contributions to the understanding of credit card misuse among working adults in Malaysia. First, the findings showed the credit card misuse by the working adults was directly related to materialism, budget constraint, impulsive buying and compulsive buying. Similar to Soman (2001), this finding suggested that Malaysian consumers had the tendency to spend beyond their means and usually make an extra purchase when they used credit cards. Many literatures highlighted the relationship between credit and indebtedness which explains the rise in consumer spending and debt (Griffiths, 2000). The findings were in line with the past studies which indicated that the desire to attain social status through material possession increases the lavish spending and credit card misuse (Fitzmaurice, 2008; Pirog \& Roberts, 2007). Moreover, this study showed that individuals with budget constrain were more exposed to credit card debt (Lyons, 2004). Furthermore, the compulsive buying behaviour itself was one of driving factors of greatest concerns because it is associated with credit debts (Roberts \& Jones, 2001) and credit card misuse (d'Astous, 1990). 
The findings also showed the compulsive buying behaviour was prevalent among working adults who had budget constraint and impulsive buying as well as embraced materialism. Since the respondents were mostly less than 40 years old, the results were also consistent with Dittmar (2005) who found that materialism contributes to the increase in compulsive buying behaviour especially among younger consumers. There was also a significant positive relationship between impulsive buying and compulsive spenders (Park \& Burns, 2005). This relationship could be attributed to the composition of medium to high income group respondents in this study. As suggested by Fogel and Schneider (2011), level of disposable income positively influences compulsive buying behaviour among consumers.

Interestingly and consistent with the intuitive prediction, self-esteem was negatively related to credit card misuse, which suggested that credit card users with low self-esteem were more likely to misuse their credit cards. This finding was in line with Wang et al. (2011) who suggested that when consumers' income is insufficient to meet their demand in pursuit of prestige, they will resort to credit cards to purchase the luxury products.

\section{Implications}

The increasing number of consumers especially young adults, who incur credit card debt is worrisome particularly if they not informed about the future consequences of their indebtedness (Roberts \& Jones, 2001). Not only consumers often use credit cards to support their modern lifestyles (Bernthal, Crockett \& Rose, 2005), there are also growing tendencies for consumers to buy compulsively (Neuner, Raab \& Reisch, 2005). The results of this study suggested significant practical implications for understanding and addressing the problem of credit card misuse not only among working adults but also the general population. The significant positive relationship between compulsive buying and credit card misuse indicated the need to educate the public about prudent financial planning and responsible credit card usage. Financial management education and courses should be introduced at the earliest age possible such as when the children begin their primary school. Moreover, parents need to take the responsibility to inculcate financial discipline to their children in order to instil the values of living within one's means.

The findings of this study also indicated that budget constraint, impulsive buying, and materialism contributed most toward compulsive buying among credit card users. In turn, low self-esteem and high compulsive buying behaviour increased the tendency of the working adults to misuse their credit cards. These findings demonstrated the importance of associating individual differences to effectively manage personal debts. These results implied that 
consumers need to be aware of their perception of money and how that attitude transcends into their credit card usage. They must be made understand that the purpose of credit card is for safe, economic and convenient mode of payment, rather than as a convenient, cost-free line of credits.

In Malaysia although, any individual above the age of 18 can possess a credit card (The Start Online, 2010), issuers of credit cards should use the findings from this study to develop advertisement campaigns and marketing strategies that promote responsible credit card usage. Socially responsible companies would benefit by designing advertisements and marketing efforts based on rational and responsible use of credit cards. Hence credit card companies should explain to potential credit cardholders on the interest rate, fees and the consequence of deferred payment of holding credit cards.

\section{Future Research}

Based on the findings as well as the variety of issues associated with compulsive buying behaviour and credit card misuse, further research may want to incorporate knowledge on financial literacy and credit card debt management, particularly among those materialistic, low self-esteem, impulsive and compulsive buyers as these groups of people prone to spend beyond their financial limits and face the financial risk. With this finding, researchers can contribute towards improving consumer financial well-being and reduce bankruptcy due to credit defaults. Another promising future research needs to be conducted with different samples of credit card users such as, college students, senior citizens and female consumers. As various segments will have different personal traits and values, for example, college students incline to have high proneness on possession of expensive and luxury products (Eren, Eroglu \& Hacioglue, 2012) this will help credit card companies and regulators to reduce the credit card debt problem.

\section{References}

AHMED, Z.U.; ISMAIL, I.; SADIQ SOHAIL, M.; TABSH, I.; ALIAS, H. (2010). Malaysian consumers' credit card usage behaviour. Asia Pacific Journal of Marketing and Logistics, 22(4): 528-544. http://dx.doi.org/10.1108/13555851011090547

ANDERSON, J.C.; GERBING, D.W. (1988). Structural equation modelling in practice: A review and recommended two-step approach. Psychological Bulletin, 103: 411-423. http://dx.doi.org/10.1037/0033-2909.103.3.411 
BAUMEISTER, R.F. (2002). Yielding to temptation: Self-control failure, impulsive purchasing, and consumer behaviour. Journal of Consumer Research, 28(4): 670-676. http://dx.doi.org/10.1086/338209

BAYLEY, G.; NANCARROW, C. (1998). Impulse purchasing: a qualitative exploration of phenomenon. Qualitative Market Research: An International Journal, 1(2): 99-114. http://dx.doi.org/10.1108/13522759810214271

BEATTY, S.E.; FERRELL, M.E. (1998). Impulse buying: Modelling its precursors. Journal of Retailing, 74(2): 169-192. http://dx.doi.org/10.1016/S0022-4359(99)80092-X

BELK, R.W. (1984). Three scales to measure constructs related to materialism: Reliability, validity, and relationships to measures of happiness. Advances in Consumer Research, 11: 291-297.

BELL, M.M. (1998). An invitation to environmental sociology. Thousand Oaks, CA: Pine Forge Press.

BERNTHAL, M.J.; CROCKETT, D.; ROSE, R.L. (2005). Credit card as lifestyle facilitators. The Journal of Consumer Research, 32(1): 130-145. http://dx.doi.org/10.1086/429605

BOLLEN, K.A. (1989). Structural equation with latent variables. New York, NY.: John Wiley \& Sons.

BRAUN, O.L.; WICKLUND, R.A. (1989). Psychological antecedents of conspicuous consumption. Journal of Economic Psychology, 10(2): 161-187. http://dx.doi.org/10.1016/0167-4870(89)90018-4

CALVERT, G. (1993). High wire management: Risk-taking tactics for leaders, innovators and trailblazers. Jossey-Bass Management Series.

CHAPLIN, L.N.; JOHN, D.R. (2007). Growing up in a material world: Age differences in materialism in children and adolescents. Journal of Consumer Research, 34. http://dx.doi.org/10.1086/518546

CHIN, W.W.; TODD, P.A. (1995). On the use, usefulness and ease of use of structural equation modelling in MIS research: A note of caution. MIS Quarterly, 19(2): 237-246. http://dx.doi.org/10.2307/249690

D'ASTOUS, A. (1990). An inquiry into the compulsive side of "normal" consumers. Journal of Consumer Policy, 13(1): 15-31. http://dx.doi.org/10.1007/BF00411867

DITTMAR, H. (2005). Compulsive buying - A growing concern? An examination of gender, age, and endorsement of materialistic values as predictors. British Journal of Psychology, 96(4): 467-492. http://dx.doi.org/10.1348/000712605X53533 
DITTMAR, H.; LONG, K.; BOND, R. (2007). When a better self is only a button click away: associations between materialistic values, emotional and identity-related buying motives, and compulsive buying tendency online. Journal of Social and Clinical Psychology, 26(3): 334-361. http://dx.doi.org/10.1521/jscp.2007.26.3.334

EASTMAN, J.K.; FREDENBERGER, B.; CAMPBELL, D.; CALVERT, S. (1997). The relationship between status consumption and materialism: a cross-cultural comparison of Chinese, Mexican, and American students. Journal of Marketing Theory and Practice, 5: 52-66.

EREN, S.S.; EROGLU, F.; HACIOGLUE, G. (2012). Compulsive buying tendencies among college students in Turkey. Procedia-Social and Behavioral Sciences, 58: 1370-1377. http://dx.doi.org/10.1016/j.sbspro.2012.09.1121

FABER, R.J.; O'GUINN, T. (1992). A clinical screener for compulsive buying. Journal of Consumer Research, 19(3): 459-469. http://dx.doi.org/10.1086/209315

FITZMAURICE, J. (2008). Splurge purchases and materialism. Journal of Consumer Marketing, 25(6): 332-338. http://dx.doi.org/10.1108/07363760810902468

FOGEL, J.; SCHNEIDER, M. (2011). Credit card use: Disposable income and employment status. Young Consumers: Insight and Ideas for Responsible Marketers, 12(1): 5-14. http://dx.doi.org/10.1108/17473611111114740

FORNELL, C.; LARCKER, D.F. (1981). Evaluating structural equation models with unobservable variables and measurement error. Journal of Marketing Research, XVIII(Feb): 39-50. http://dx.doi.org/10.2307/3151312

GAO, L.; WHEELER, S.C.; SHIV, B. (2009). The "Shaken Self": Product choices as a means of restoring self-view confidence. Journal of Consumer Research, 36(1): 29-38. http://dx.doi.org/10.1086/596028

GEISST, C.R. (2009). The marketing of consumer debt to America. NY: Bloomberg Press.

GRIFFITHS, M. (2000). The sustainability of consumer credit growth in late twentieth century Australia. Journal of Consumer Studies \& Home Economics, 24(1): 23-33. http://dx.doi.org/10.1046/j.1365-2737.2000.00117.x

GROSS, D.B.; SOULELES, N.S. (2002). An empirical analysis of personal bankruptcy and delinquency. Review of Financial Studies, 15(1): 319-347. http://dx.doi.org/10.1093/rfs/15.1.319

HAIR, F.J.; BLACK, W.C.; BABIN, B.; ANDERSON, R.E.; TATHAM, R.L. (2006). Multivariate Data Analysis. Upper Saddle River, NJ.: Prentice-Hall.

HANLEY, A.; WILHELM, M.S. (1992). Compulsive buying: An exploration into self-esteem and money attitudes. Journal of Economic Psychology, 13(1): 5-18. http://dx.doi.org/10.1016/01674870(92)90049-D 
HAYHOE, C.R.; LEACH, L.J.; TURNER, P.R.; BRUIN, M.J.; LAWRENCE, F.C. (2000). Differences in spending habits and credit use of college students. Journal of Consumer Affairs, 34(1): 113-133. http://dx.doi.org/10.1111/j.1745-6606.2000.tb00087.x

HEANEY, J.G.; GOLDSMITH, R.E.; JUSOH, W.J.W. (2005). Status consumption among Malaysian consumers: Exploring its relationships with materialism and attention-to-social-comparisoninformation. Journal of International Consumer Marketing, 17(4): 83-98. http://dx.doi.org/10.1300/J046v17n04_05

HU, L.; BENTLER, P.M. (1999). Cut-off criteria for fit indexes in covariance structure analysis: Conventional criteria versus new alternatives. Structural Equation Modeling, 6(1): 1-55. http://dx.doi.org/10.1080/10705519909540118

KASSER, T.; SHELDON, K.M. (2000). Of wealth and death: Materialism, mortality salience, and consumption behaviour. Psychological Science, 11(4): 348-351. http://dx.doi.org/10.1111/14679280.00269

KLINE, R.B. (2005). Principles and Practice of Structural Equation Modeling. New York, NY: The Guilford Press.

KRUEGER, D.W. (1988). On compulsive shopping and spending: A psychodynamic inquiry. American Journal of Psychotherapy, 42(2): 574-584.

LOKE, Y.J. (2007). Determinants of merchant participation in credit card payment schemes. Review of Network Economics, 6(4): 474-494. http://dx.doi.org/10.2202/1446-9022.1130

LYONS, A.C. (2004). A profile of financially at-risk college students. Journal of Consumer Affairs, 38(1): 56-80. http://dx.doi.org/10.1111/j.1745-6606.2004.tb00465.x

MITTAL, V.; HUPPERTZ, J.W.; KHARE, A. (2008). Customer complaining: The role of tie strength and information control. Journal of Retailing, 84(2):195-204. http://dx.doi.org/10.1016/j.jretai.2008.01.006

NEUNER, M.; RAAB, G.; REISCH, L.A. (2005). Compulsive buying in maturing consumer societies: An empirical re-inquiry. Journal of Economic Psychology, 26(4): 509-522. http://dx.doi.org/10.1016/j.joep.2004.08.002

NORVILITIS, J.M.; MERWIN, M.M.; OSBERG, T.M.; ROEHLING, P.V.; YOUNG, P.; KAMAS, M.M.; (2006). Personality factors, money attitudes, financial knowledge, and credit card debt in college students. Journal of Applied Social Psychology, 36(6): 1395-1413. http://dx.doi.org/10.1111/j.0021-9029.2006.00065.x

NUNNALLY, I. (1978). Psychometric Theory. New York: McGraw-Hill.

PALAN, K.M.; MORROW, P.C.; TRAPP II, A.; BLACKBURN, V. (2011). Compulsive buying behaviour in college students: The mediating role of credit card misuse. Journal of Marketing Theory and Practice, 19(1): 81-96. http://dx.doi.org/10.2753/MTP1069-6679190105 
PARK, H.J.; BURNS, L.D. (2005). Fashion orientation, credit card use, and compulsive buying. Journal of Consumer Marketing, 22(3): 135-141. http://dx.doi.org/10.1108/07363760510595959

PASSPORT. (2011). Credit card transactions in Malaysia. Euro monitor International.

PETTIT, N.C.; SIVANATHAN, N. (2011). The plastic trap: Self-threat drives credit usage and status consumption. Social Psychological and Personality Science, 2:146-153. http://dx.doi.org/10.1177/1948550610385138

PETTIT, N.C.; SIVANATHAN, N. (2011). The plastic trap: Self-threat drives credit usage and status consumption. Social Psychological and Personality Science, 2(2): 146-153. http://dx.doi.org/10.1177/1948550610385138

PINDYCK, R.S.; RUBINFELD, D.L. (2008). Microeconomics. Pearson.

PINTO, M.B.; MANSFIELD, P.M.; PARENTE, D.H. (2004). Relationship of credit attitude and debt to self-esteem and locus of control in college-age consumers. Psychological Reports, 94(3c): 1405-1418. http://dx.doi.org/10.2466/pro.94.3c.1405-1418

PIROG III, S.F.; ROBERTS, J.A. (2007). Personality and credit card misuse among college students: The mediating role of impulsiveness. Journal of Marketing Theory and Practice, 15(1): 65-77. http://dx.doi.org/10.2753/MTP1069-6679150105

PRINCE, M. (1993). Women, men and money styles. Journal of Economic Psychology, 14(1): 175-182. http://dx.doi.org/10.1016/0167-4870(93)90045-M

RICHINS, M.L. (2011). Materialism, transformation expectations, and spending: Implications for credit use. Journal of Public Policy \& Marketing, 30(2): 141-156. http://dx.doi.org/10.1509/jppm.30.2.141

RICHINS, M.L.; DAWSON, S. (1992). A consumer values orientation for materialism and its measurement: Scale development and validation. Journal of Consumer Research, 19(3): 303-316. http://dx.doi.org/10.1086/209304

RICHINS, M.L.; RUDMIN, F. (1994). Materialism and economic psychology. Journal of Economic Psychology, 15: 217-231. http://dx.doi.org/10.1016/0167-4870(94)90001-9

ROBERTS, J.A.; JONES, E. (2001). Money attitudes, credit card use, and compulsive buying among American college students. The Journal of Consumer Affairs, 35(21): 213-240. http://dx.doi.org/10.1111/j.1745-6606.2001.tb00111.x

ROOK, D.W. (1987). The buying impulse. Journal of Consumer Research, 14(2): 189-199. http://dx.doi.org/10.1086/209105

ROOK, D.W.; FISHER, R.J. (1995). Normative influences on impulsive buying behaviour. Journal of Consumer Research, 22(3): 305-313. http://dx.doi.org/10.1086/209452 
ROSENBERG, M. (1965). Research and evaluation method. Princeton, NJ: Princeton University Press.

ROSENBERG, M. (1979). Conceiving the self. USA: Basic Books.

SCHIFFMAN, L. G.; KANUK, L. L. (2007). Consumer Behavior. NJ: Prentice Hall.

SHOHAM, A.; BRENCIC, M.M. (2003). Compulsive buying behaviour. Journal of Consumer Marketing, 20(2/3): 127-138. http://dx.doi.org/10.1108/07363760310464596

SIDOTI, P.M.; DEVASAGAYAM, R. (2010). Credit cards and college students: Effect of materialism and risk attitude on misuse. The Marketing Management Journal, 20(2): 64-79.

SIRGY, M.J. (1998). Materialism and quality of life. Social Indicators Research, 43(3): 227-260. http://dx.doi.org/10.1023/A:1006820429653

SOMAN, D. (2001). Effects of payment mechanism on spending behaviour: The role of rehearsal and immediacy of payment. Journal of Consumer Research, 27(4): 460-474. http://dx.doi.org/10.1086/319621

TOKUNAGA, H. (1993). The use and abuse of consumer credit: Application of psychological theory and research. Journal of Economic Psychology, 14(2): 285-316. http://dx.doi.org/10.1016/0167-4870(93)90004-5

URBANY, J.E.; DICKSON, P.R.; KALAPURAKAL, R. (1996). Price search in the retail grocery market. The Journal of Marketing, 60(2): 91-104. http://dx.doi.org/10.2307/1251933

WANG, J.; XIAO, J.J. (2009). Buying behaviour, social support and credit card indebtedness of college students. International Journal of Consumer Studies, 33: 2-10. http://dx.doi.org/10.1111/j.1470-6431.2008.00719.x

WANG, L.; LV, W.; JIANG, L. (2011). The impact of attitude variables on the credit debt behaviour. Nankai Business Review International, 2(2): 120-139. http://dx.doi.org/10.1108/20408741111139909

WARWICK, J.; MANSFIELD, P. (2000). Credit card consumers: College students' knowledge and attitude. Journal of Consumer Marketing, 17(7): 617-626. http://dx.doi.org/10.1108/07363760010357813

WOODRUFFE, H.R. (1997). Compensatory consumption: Why women go shopping when they're fed up and other stories. Marketing Intelligence \& Planning, 15(7): 325-334. http://dx.doi.org/10.1108/02634509710193172

YAMUCHI, K.T.; TEMPLER, D.I. (1982). The development of a money attitude scale. Journal of Personality Assessment, 46(5): 522-528. http://dx.doi.org/10.1207/s15327752jpa4605_14

YELSMA, P.; YELSMA, J. (1998). Self-esteem and social respect within the high school. Journal of social psychology, 138(4): 431-442. http://dx.doi.org/10.1080/00224549809600398 


\section{Appendix}

\section{Research model measures}

\begin{tabular}{|c|c|c|}
\hline Constructs & $\begin{array}{l}\text { Source of } \\
\text { Items }\end{array}$ & Items \\
\hline Self-Esteem & $\begin{array}{l}\text { Rosenberg } \\
(1965)\end{array}$ & $\begin{array}{l}\text { 1. I feel that I have a number of good qualities. } \\
\text { 2. I am able to do things as well as most people. } \\
\text { 3. I feel that I am a person of worth, at least on an equal } \\
\text { plane with others. }\end{array}$ \\
\hline Materialism & $\begin{array}{l}\text { Richins \& } \\
\text { Dawson (1992) }\end{array}$ & $\begin{array}{l}\text { 1. I admire people who own expensive homes, cars and } \\
\text { clothes. } \\
\text { 2. I like to own things that impress people. } \\
\text { 3. I always pay attention to material objects that others own. } \\
\text { 4. The things I own say a lot to others in terms of how my } \\
\text { life is. } \\
\text { 5. I always buy what I want, not what I need. } \\
\text { 6. Buying things gives me a lot of pleasure. }\end{array}$ \\
\hline $\begin{array}{l}\text { Budget } \\
\text { Constraints }\end{array}$ & $\begin{array}{l}\text { Urbany et al. } \\
(1996)\end{array}$ & $\begin{array}{l}\text { 1. I always have problems paying my bills every month. } \\
\text { 2. My budgeting is always tight. } \\
\text { 3. I often have to spend more money than I have or can } \\
\text { afford. } \\
\text { 4. I always do not have enough money to spend every } \\
\text { month. } \\
\text { 5. I do not have any savings in my bank account for } \\
\text { emergency. } \\
\text { 6. I always borrow money from others to make ends meet. }\end{array}$ \\
\hline $\begin{array}{l}\text { Impulsive } \\
\text { Buying }\end{array}$ & $\begin{array}{l}\text { Rook \& Fisher } \\
\text { (1995) }\end{array}$ & $\begin{array}{l}\text { 1. I often buy things spontaneously. } \\
\text { 2. 'Just do it' describes the way I buy things. } \\
\text { 3. I often buy things without thinking. } \\
\text { 4. Most of the time I buy things on the spur of the moment. } \\
\text { 5. I do not plan most of my purchases. } \\
\text { 6. I am always reckless about what I buy. }\end{array}$ \\
\hline $\begin{array}{l}\text { Compulsive } \\
\text { Buying }\end{array}$ & $\begin{array}{l}\text { Faber \& O'Guinn } \\
(1992)\end{array}$ & $\begin{array}{l}\text { 1. I feel others will be horrified if they know of my spending } \\
\text { habits. } \\
\text { 2. I buy things even though I cannot afford them. } \\
\text { 3. I feel anxious or nervous on days I do not go shopping. } \\
\text { 4. I make only the minimum payments on my credit cards. }\end{array}$ \\
\hline $\begin{array}{l}\text { Credit } \\
\text { Misuse }\end{array}$ & $\begin{array}{l}\text { Roberts \& Jones } \\
\text { (2001) }\end{array}$ & $\begin{array}{l}\text { 1. I am less concerned with the price of a product when I use } \\
\text { a credit card. } \\
\text { 2. I am more impulsive when I shop with credit cards. } \\
\text { 3. I am always late in making payments on my credit cards. } \\
\text { 4. I spend over my available credit limit most of the time. } \\
\text { 5. I often take cash advances on my credit cards. } \\
\text { 6. I often make only the minimum payment on my credit card } \\
\text { bills. }\end{array}$ \\
\hline
\end{tabular}

Intangible Capital, 2014 (www.intangiblecapital.org)

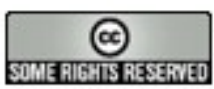

Article's contents are provided on a Attribution-Non Commercial 3.0 Creative commons license. Readers are allowed to copy, distribute and communicate article's contents, provided the author's and Intangible Capital's names are included. It must not be used for commercial purposes. To see the complete license contents, please visit http://creativecommons.org/licenses/by-nc/3.0/. 